ognition of the potential for strong ground motions and the coseismic development of 1to 2-m-high, <145-m-wide fold scarps associated with $\mathrm{Mw} \geq 7$ earthquakes on the PHT will help to refine seismic hazard plans and policies in this large metropolitan region.

References and Notes

1. K. E. Sieh, J. Geophys. Res., 83, 3907 (1978).

2. D. P. Schwartz, K. J. Coppersmith, J. Geophys. Res. 89, 5681 (1984).

3. J. Suppe, G. T. Chou, S. C. Hook, in Thrust Tectonics, K. R. McClay, Ed. (Chapman Hall, London, 1992), pp. 105-121.

4. J. H. Shaw, J. Suppe, Geol. Soc. Am. Bull. 106, 607 (1994).

5. C. Schneider, C. Hummon, R. S. Yeats, G. Huftile, Tectonics 15, 341 (1996).

6. E. Novoa, J. Suppe, J. H. Shaw, Am. Assoc. Pet. Geol. Bull. 84, 787 (2000).

7. J. H. Shaw, P. M. Shearer, Science 283, 1516 (1999).

8. J. F. Dolan, Geol. Soc. Am. Abstracts with Programs, Cordilleran Section Meeting, 30, 12 (abstr.) (1998).

9. J. H. Shaw, A. Plesch, J. F. Dolan, T. L. Pratt, P. Fiore, Bull. Seismol. Soc. Am. 92, 2946 (2002).

10. T. L. Pratt et al., Geophys. Res. Lett. 29, 18-1 (2002).

11. Gumprecht (21) reports that before urbanization, much of the Los Angeles basin and northern Orange County, including our study site, was an extensive, frequently flooded marshy region. Thus, the Carfax site was an aggradational setting through early historic time.

12. We also excavated a north-south transect comprising seven boreholes in an agricultural field $30 \mathrm{~m}$ east of the Carfax transect. Both transects penetrated the same stratigraphic section, demonstrating that all strata are laterally continuous both north to south and east to west.

13. H. Blatt, G. Middleton, R. Murray, Origin of Sedimentary Rocks (Prentice-Hall, Englewood Cliffs, NJ, 1980).

14. Materials and methods are available as supporting material on Science Online.

15. Event $Y$, the most recent earthquake, is recorded by a $1.0 \pm 0.1 \mathrm{~m}$-high scarp capped by the buried Unit 12 paleosol. This buried fold scarp is onlapped by Units 10 and 11. Penultimate Event $X$ is recorded by $1.0 \pm 0.2 \mathrm{~m}$ of southward thickening of the Units 20 to 25 section, which reflects uplift and subsequent burial of a 1-mhigh fold scarp that developed after the end of Unit 30 deposition and before the end of Unit 20 deposition. Event $X$ followed a period of structural quiescence during deposition of Units 30 and 35. Event $V$, the oldest episode of discrete fold growth that we can identify, is recorded by $2.2 \mathrm{~m}$ of southward thickening of the Units 50 to 55 section. Event $V$ occurred after deposition of Unit 60 , probably after deposition of Unit 55 at $\sim 10.2$ to $10.7 \mathrm{ka}$ (14), and before the end of deposition of the Unit 50 gravel channel at $\sim 9.5$ to $10.0 \mathrm{ka}$. Progressive downward thickening of units below Unit 55 in the southern part of the transect records additional latest Pleistocene uplift (for example, the Unit 61 paleosol exhibits an additional $2 \mathrm{~m}$ of structural relief), but we cannot distinguish discrete structural events in this gravel-dominated section.

16. Alternatively, if each of the stratigraphically discrete uplift events records multiple moderate-sized earthquakes, rather than a single large event, these smaller earthquakes must have occurred during brief clusters, on the order of no more than about a thousand years in the cases of Events $\mathrm{W}$ and $\mathrm{V}$, for example. For comparison, at least 6 to 10 Northridge-sized (Mw 6.7) earthquakes would have had to occur to account for the displacement observed during Event W (18). We consider this possibility unlikely and favor the single-event interpretation for each of these temporally discrete uplift events. Moreover, the episodic development of the fold scarps obviates the possibility that the folds grow quasicontinuously in response to fault creep on the PHT.

17. In a long-term sense, the minimum displacements that we measured cannot all represent maximum slip values in all four earthquakes, because the Carfax site records only $\sim 65 \%$ of maximum slip along the Santa Fe Springs segment (9).
18. D. Wells, K. Coppersmith, Bull. Seismol. Soc. Am. 84 974 (1994).

19. Shaw et al. (9) estimated the maximum magnitude for PHT earthquakes at $\mathrm{Mw} \sim 7.1$, somewhat smaller than our suggested magnitudes, especially for Events W and $V$. Their analysis, however, extended only to the northwestern limit of high-quality petroleum-industry seismic reflection data, at a point $\sim 4 \mathrm{~km}$ northwest of downtown Los Angeles. Dolan (8) suggested that geomorphic evidence for young folding (uplifted older alluvium and drainages diverted around the western nose of a young, west-northwest-trending anticline) indicates that the PHT has propagated westward into the Beverly Hills area, $\sim 10$ to $15 \mathrm{~km}$ west of downtown Los Angeles. This would almost double the area of the PHT Los Angeles segment ramp and would increase the total fault-plane area of the PHT system by as much as $\sim 25 \%$, adding substantially to the size of a systemwide rupture. Alternatively, the PHT may rupture together with adjacent faults.

20. Excluding the San Andreas fault, the largest earthquakes to occur on Los Angeles region faults during the historic period ( $\sim 1775$ to present) are the 1971 San Fernando and 1994 Northridge earthquakes, both of which were Mw 6.7. Our observations add to a growing body of evidence that shows that the historic period in the Los Angeles area has been part of a seismic "lull" that is not representative of the long-term patterns of seismic strain release in the region, in terms of both earthquake sizes and moment-release rates (22).

21. B. Gumprecht, The Los Angeles River: Its Life, Death, and Possible Re-Birth (Johns Hopkins Univ. Press, Baltimore, 1999).

22. J. F. Dolan et al., Science 267, 199 (1995).

23. This study was funded by the U.S. Geological Survey (USGS) National Earthquake Hazards Reduction Program (NEHRP) grants 01HQGR0101, 02HQGR0042, and 00HQGRO006, and by the Southern California Earthquake Center (SCEC). SCEC is supported by NSF grant EAR-0106924 and USGS NEHRP grant 02HQAC0009. This is SCEC publication 713. We thank T. Pratt, A. Plesch, R. Hartleb, K. Austin, S. Marsic, and M. Marin for their contributions to this work.

Supporting Online Material www.sciencemag.org/cgi/content/full/300/5616/115/ DC1

Supporting Text

Fig. S1

Table S1

References and Notes

18 November 2002; accepted 6 March 2003

\title{
Mediterranean Moisture Source for an Early-Holocene Humid Period in the Northern Red Sea
}

\author{
Helge W. Arz, ${ }^{1 * \dagger}$ Frank Lamy, ${ }^{1 *}$ Jürgen Pätzold, ${ }^{1}$ Peter J. Müller, ${ }^{1}$ \\ Maarten Prins ${ }^{2}$
}

Paleosalinity and terrigenous sediment input changes reconstructed on two sediment cores from the northernmost Red Sea were used to infer hydrological changes at the southern margin of the Mediterranean climate zone during the Holocene. Between approximately 9.25 and 7.25 thousand years ago, about $3 \%$ reduced surface water salinities and enhanced fluvial sediment input suggest substantially higher rainfall and freshwater runoff, which thereafter decreased to modern values. The northern Red Sea humid interval is best explained by enhancement and southward extension of rainfall from Mediterranean sources, possibly involving strengthened early-Holocene Arctic Oscillation patterns and a regional monsoon-type circulation induced by increased land-sea temperature contrasts. We conclude that Afro-Asian monsoonal rains did not cross the subtropical desert zone during the early to mid-Holocene.

Though from a long-term perspective, the Holocene is commonly seen as a relative stable climatic period, the tropics and sub-

tropics and also the Mediterranean climate zone were subject to large amplitude changes in the hydrological cycle (1-5). Currently,
Fig. 1. Map with location of sites discussed in the text: 1, core GeoB 5804-4 (this study); 2, core GeoB 5844-2 (this study); 3 , core KL 11 (16); 4, Soreq Cave (18); 5 , core LC21 (29); 6, ODP Site $658 \mathrm{C}$ (6). The map also includes a schematic representation of modern rainfall regimes showing the $100 \mathrm{~mm} /$ year isohyets as limits of winter and summer rainfall regimes [after (25)].

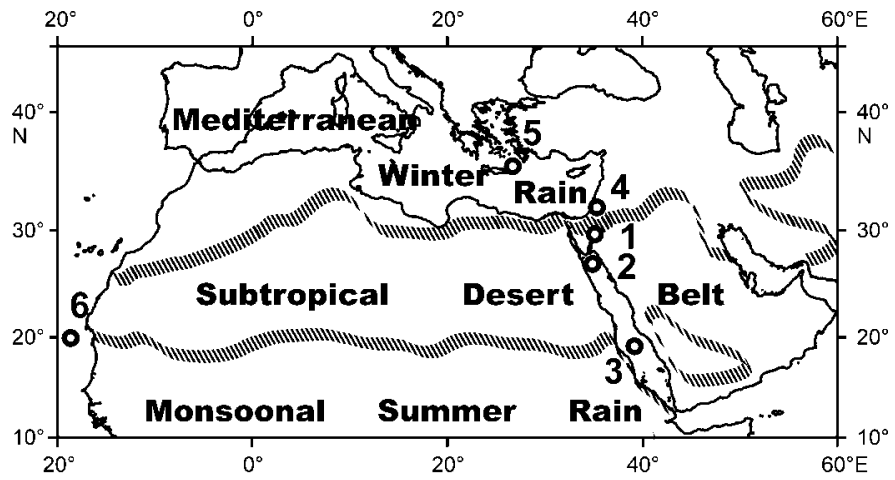


there is no overlap between the spheres of Afro-Asian summer monsoonal rains and Mediterranean winter cyclonic rains because the systems are separated by the Arabian and Sa- hara desert belt (Fig. 1). Maximum Northern Hemisphere summer insolation during the early Holocene caused a substantial increase and northward extension of monsoonal summer

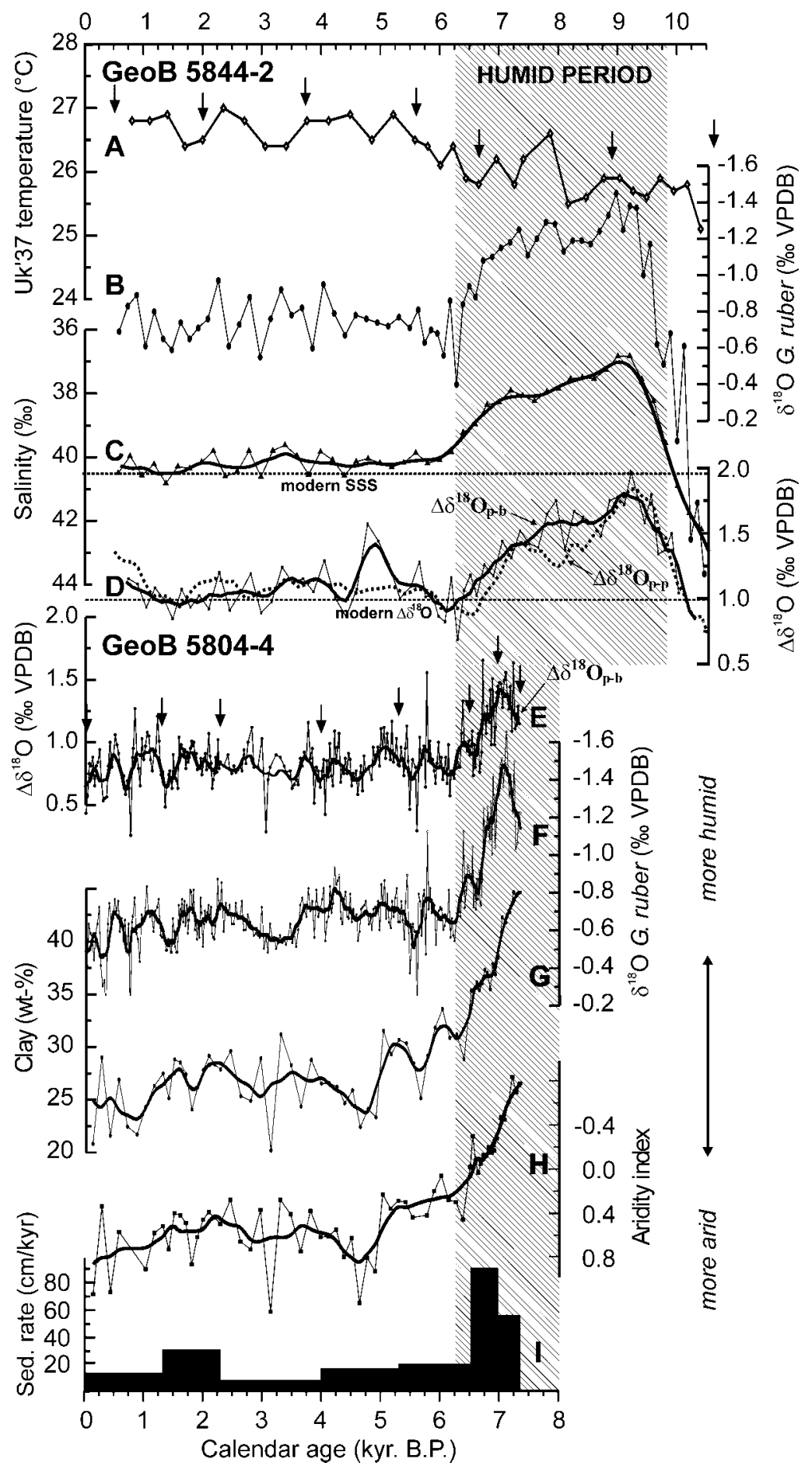

Fig. 2. Holocene proxy records from the northern Red Sea sediment cores GeoB 5844-2 and GeoB 5804-4. (A) Uk'37 paleotemperature, (B) $\delta^{18} \mathrm{O}$ record of G. ruber (white), (C) paleosalinity, and (D) $\Delta \delta^{18} \mathrm{O}$ records $\left[\Delta \delta^{18} \mathrm{O}_{\text {p-b }}\right.$ was calculated as the difference between G. ruber (white) and C. mabahethi, and $\Delta \delta^{18} \mathrm{O}_{\mathrm{p}-\mathrm{p}}$ was calculated as the difference between $G$. ruber (white) and $L$. inflata] reconstructed from core GeoB 5844-2, (E) $\Delta \delta^{18} \mathrm{O}_{\mathrm{p}-\mathrm{b}}$ record, (F) $\delta^{18} \mathrm{O}$ record of $G$. ruber (white), (G) clay content, (H) aridity index, and (I) sedimentation rates reconstructed from core GeoB 5804-4. Original data in (C) to $(\mathrm{H})$ have been smoothed by simple moving averaging (bold lines). Arrows at the top of $(A)$ and $(E)$ indicate ${ }^{14} \mathrm{C}$ dates used for constructing the age models of GeoB 5844-2 and GeoB 5804-4, respectively (table $\mathrm{S} 1$ ).

rains in both subtropical northern Africa $(2,3$, $6)$ and southwest Asia $(7,8)$, restricting the desert belt to a much smaller extent (9). Also in the Mediterranean zone, summer rains apparently increased during the early to mid-Holocene $(5,10)$, which might even reflect an extension of the Afro-SW-Asian monsoon regime north of the modern desert belt (10). Increased regional rainfall in the Mediterranean together with enhanced fresh water discharge from external sources, i.e., the Nile (11) and possibly the Black Sea (12), contributed considerably to the formation of the well-known sapropel S1 in the eastern Mediterranean. Whereas the Nile freshwater discharge is clearly controlled by changes in African monsoonal precipitation (11), the source and mechanisms for increased regional rainfall in the eastern Mediterranean has not been determined unequivocally.

A particularly suitable region that can be studied to resolve this question is the Red Sea, which is presently located between the Mediterranean and Afro-SW-Asian monsoonal rainfall regimes (Fig. 1). The northernmost Red Sea area presently receives rare winter rain (10 to $25 \mathrm{~mm} /$ year) from depressions and associated cold frontal troughs from the Mediterranean. Whereas the central Red Sea is subjected to locally increased winter precipitation related to converging north-northeast and southwest winds, a monsoonal influenced summer precipitation is observed in the southernmost part (13). Excess evaporation and the particular Red Sea bathymetry, restricting the seawater exchange with the Indian Ocean through the shallow Strait of Bab el Mandeb (about 137 m below sea level), give rise to an antiestuarine circulation with exceptionally high sea surface salinities of about $40.6 \%$ in the northern Red Sea (14).

Here, we assumed that the Holocene salinity changes within this restricted marginal sea are very sensitive to the regional hydrological balance. Therefore, we combined proxy data for past surface ocean properties and continental rainfall on the basis of two well-dated high-resolution sediment cores from the northernmost part of the Gulf of Aqaba (GeoB 5804-4) and off the southern tip of the Sinai Peninsula (GeoB 5844-2) (15) (Fig. 1) and compared these data to a paleoceanographic record from the central Red Sea (16).

Paleosalinities were calculated by combining stable oxygen isotope data on plank-

${ }^{1}$ Deutsche Forschungsgemeinschaft (DFG) Research Center for Ocean Margins, University of Bremen, Klagenfurter Strasse, 28359 Bremen, Germany. ${ }^{2}$ Faculty of Earth Sciences, Vrije Universiteit Amsterdam, De Boelelaan 1085, 1081 HV Amsterdam, Netherlands.

*These authors contributed equally to the paper. $\dagger$ To whom correspondence should be addressed. Email: helge.arz@uni-bremen.de 
tonic foraminifera with $\mathrm{U}_{37}^{\mathrm{k}^{\prime}}$ paleotemperature estimates (Core GeoB 5844-2) (15). Past sea surface temperatures (SSTs) show a gradual warming trend from $\sim 25^{\circ}$ to $\sim 27^{\circ} \mathrm{C}$ in the course of the Holocene (Fig. 2A). In contrast, stable oxygen isotope data of the shallowdwelling planktonic foraminifera Globigerinoides ruber (white) indicate up to $\sim 0.8$ per mil (\%o) lighter $\delta^{18} \mathrm{O}$ values between 9.8 and 6.25 thousand years ago $(\mathrm{ka})$ compared with the Holocene background level. Since then, $\delta^{18} \mathrm{O}$ values fluctuated only slightly around this level (Fig. 2B). These data result in reduced salinities up to $\sim 3 \%$ between 9.25 to $7.25 \mathrm{ka}$ and a rapid increase until $\sim 6.25 \mathrm{ka}$ to the middle to late Holocene level, which corresponds approximately to the modern surface water salinities (Fig. 2C). In the earliest Holocene (before $9.8 \mathrm{ka}$ ) and the late glacial periods, salinities were even higher than at present (17). Assuming similar Holocene paleotemperature trends at the Gulf of Aquaba core site (GeoB 5804-4), an equivalent shift in the planktonic $\delta^{18} \mathrm{O}$ record $(\sim 0.8 \%)$ at this core location implies that the freshening of surface waters was regional in the northern Red Sea during the early to mid-Holocene (Fig. 2F).

The surface water freshening was accompanied by substantial changes in water column stratification. Vertical $\delta^{18} \mathrm{O}$ gradients, expressed as the difference between the planktonic foraminifera G. ruber (white) and the benthic foraminifera Cibicidoides mabahethi $\delta^{18} \mathrm{O}$ record $\left(\Delta \delta^{18} \mathrm{O}_{\mathrm{p}-\mathrm{b}}\right)$, were much higher during the low-salinity interval and reached up to $\sim 1.8$ and $\sim 1.5 \%$ compared with modern (and middle to late Holocene) values of $\sim 1$ and $\sim 0.7 \%$ o at site GeoB 5844-2 and GeoB 5804-4, respectively (Fig. 2, D and E). The comparison of the $\delta^{18} \mathrm{O}$ records of $G$. ruber (white) and the deep planktonic diel-migratory mesopelagic pteropod Limacina inflata (GeoB 5844-2; $\Delta \delta^{18} \mathrm{O}_{\mathrm{p}-\mathrm{p}}$ ) suggests that the freshening was restricted to $<100 \mathrm{~m}$ of the water column (Fig. 2D).

Terrigenous sediment composition and its supply rate to the Gulf of Aqaba changed dramatically at the end of the early- to mid-Holocene low-salinity period, and the change is reflected by the sedimentation rate and clay content records, which decreased to one-fourth and one-half, respectively (Fig. 2, G and I). End member modeling of the grain-size distributions of the terrigenous sediment fraction (15) indicate that these changes are related to a shift in the dominant mode of sediment transport. The strong reduction in fluvial sediment supply and the increase in eolian sediment supply at the end of the early- to mid-Holocene lowsalinity period indicate a substantial decrease in regional rainfall (Fig. $2 \mathrm{H}$ ).

Within the errors of dating, the humid period that is reconstructed here correlates very well to the more humid conditions in the eastern Mediterranean region. $\delta^{18} \mathrm{O}$ analyses of spe- leothems at Soreq Cave (Israel), $\sim 250-\mathrm{km}$ north of site GeoB 5804-4, suggest that there was up to twice the regional rainfall $(\sim 1000$ $\mathrm{mm} / \mathrm{a}$ ) between $\sim 10$ and $7 \mathrm{ka} \mathrm{(18)} \mathrm{(Fig.} \mathrm{3B).}$ However, at Soreq a final reduction to modern levels occurred later $(\sim 4 \mathrm{ka})$ than in the northern Red Sea. This suggests that the whole region was humid only during the maximum wet phase and that enhanced precipitation thereafter was restricted to more coastal, orographically favorable areas. The northern Red Sea humid interval also corresponds to sapropel S1 in the eastern Mediterranean (Fig. 3A), which has been at least partly related to enhanced regional rainfall $(5,19)$.

If increased regional rainfall in the southeast Mediterranean and northern Red Sea originated from a northward extension of the African and southwest-Asian monsoons, early- to mid-Holocene low-salinity surface water conditions would have been even more pronounced in the central and southern Red Sea. At present the north-south salinity gradient of $\sim 4$ to $5 \%$ in the Red Sea strongly reflects the highly arid conditions within the entire basin. This latitudinal gradient is fairly well documented in the modern foraminiferal $\delta^{18} \mathrm{O}(20)$ (Fig. 4). Tracing the gradient back through the Holocene shall enable us to differentiate southern from northern moisture sources. For this purpose, we compared our records with a $G$. ruber (white) record from the central Red Sea sediment core KL $11(16,21)$. During the early Holocene ( 9.25 to $7.25 \mathrm{ka}$ ), the latitudinal gradient between these sites is clearly

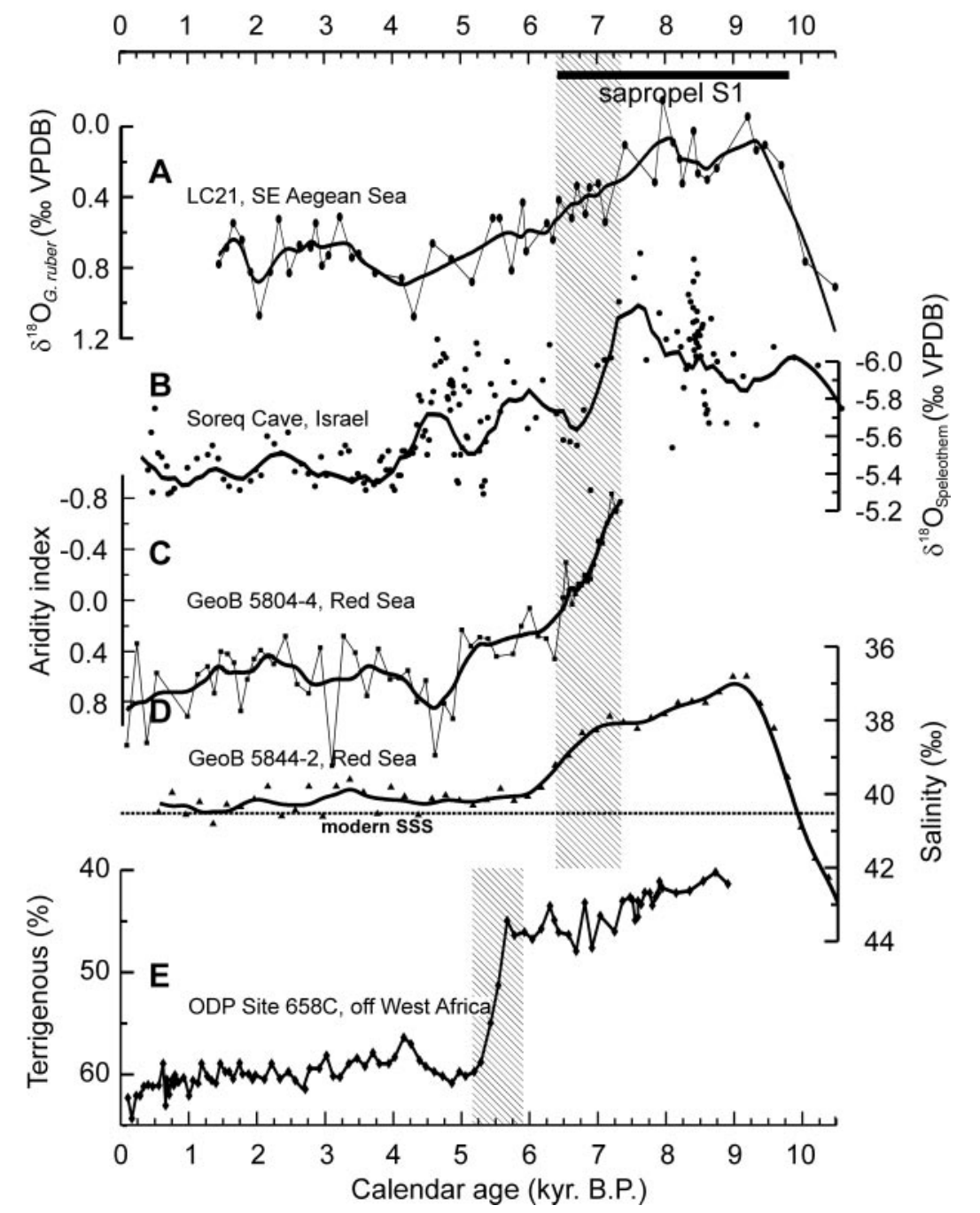

Fig. 3. Timing of the early- to mid-Holocene humid interval in the northern Red Sea compared with proxy records from the eastern Mediterranean, southern Oman, and West Africa. (A) $\delta^{18} \mathrm{O}$ record of G. ruber (white) of the southeast Aegean Sea core LC21 (29), marking the enhanced freshwater flux to the eastern Mediterranean Sea. Black bar indicates the extent of anoxic sedimentation in LC21, representing sapropel S1. (B) $\delta^{18} \mathrm{O}$ speleothem record, Soreq Cave, as a proxy for regional rainfall in Israel (18). (C) Aridity index from the northern Gulf of Aqaba core GeoB 5804-4 (this study). (D) Paleosalinity record from the northern Red Sea core GeoB 5844-2 (this study). (E) Eolian sedimentation, ODP Site 658C, off West Africa as a proxy for aridity in subtropical North Africa (6). Original data in (A) to (D) have been smoothed by simple moving averaging (bold lines). Vertical bars emphasize the major humid to arid transition in the various records. 
at its minimum $(\sim 0.3 \%)$, and it increases after the end of the northern Red Sea humid period to modern values of $\sim 1.5 \%$. Because there is no clear evidence of surface water freshening in the central Red Sea and the isotopic record most probably reflects only the gradual temperature increase throughout the Holocene, we conclude that monsoonal precipitation was not substantially increased in the central Red Sea. Hence, our data strongly suggest a northern source of moisture.

Lower than modern early- to mid-Holocene Mediterranean (22) have been interpreted in terms of enhanced inflow of cold continental air masses primarily during winter, a pattern that resembles the modern high phase of the Arctic Oscillation (AO) (23). Associated with the high phase of the $\mathrm{AO}$, positive winter rainfall anomnean region [Supporting Online Material (SOM) Text, fig. S1]. Projected onto the early to mid-Holocene, this would suggest increased winter precipitation. Considering, however, the magnitude of modern AO-related precipitation anomalies, this mechanism alone was probably not capable of supplying sufficient moisture to the region. Therefore, an additional mechanism involves the generation of a regional monsoontype circulation pattern over the southeast Mediterranean. Elevated land-sea temperature contrasts due to lower early- to mid-Holocene SSTs and to simultaneous insolation-induced higher land temperatures could have facilitated the inflow of moist air masses from the eastern Mediterranean to the surrounding land masses, penetrating south into the northern Red Sea region. This scenario is supported by pollen and lake-level data from the eastern Mediterranean, which likewise suggest that particularly summer rainfall increased during the early to mid-Holocene $(5,10,18)$. An alternative mechanism, which involves enhanced rainfall resulting from a northward shift of the small convergence zone presently SSTs in the northern Red Sea and in the eastern alies are observed in the southeast Mediterra-

located in the central Red Sea, is rather unlikely. Northward-deflected Asian winter monsoons, which currently control the location of the convergence, were reduced during the early Holocene (24), suggesting a southward displacement of this zone.

A further argument for decoupling of southeast Mediterranean and Afro-Asian monsoonal rainfall is the timing of the termination of the early- to mid-Holocene humid interval. Speleothem records from northern $\operatorname{Oman}(7,8)$ and various lake-level records from monsoon-dominated sites in the southern Sahara and the Sahelian belt $(2,3,25)$ indicate that the end of the humid interval occurred between 6 and $4 \mathrm{ka}$. A marine record off West Africa representing an integrated aridity record for the western Sahara and Sahel (6) shows the onset of more arid conditions to be about $5.5 \mathrm{ka}$. Thus, the termination of the humid period in the monsoonal belt occurred much later than in the southeast Mediterranean and the northern Red Sea (Fig. $3 \mathrm{E})$. Though both humid periods are primarily controlled by the early-Holocene summer insolation maximum, climate model studies suggest that vegetational feedbacks prolonged the humid period, particularly in Africa $(6,26)$. A possible explanation could be that such vegetational feedback had a smaller effect in the southeast Mediterranean and northern Red Sea.

Most climate models simulate enhanced winter rain for the Mediterranean during the early to mid-Holocene (27). Likewise, regional climate models for the Mediterranean under different global warming scenarios indicate decreased summer precipitation (28), suggesting that the generation of a regional monsoon-type circulation pattern might not be well simulated by models. We speculate that a "Mediterranean monsoon" as well as long-term changes in the AO patterns might have a strong impact on future precipitation in the heavily populated southeast Mediterranean and Near East region under the projected global warming,

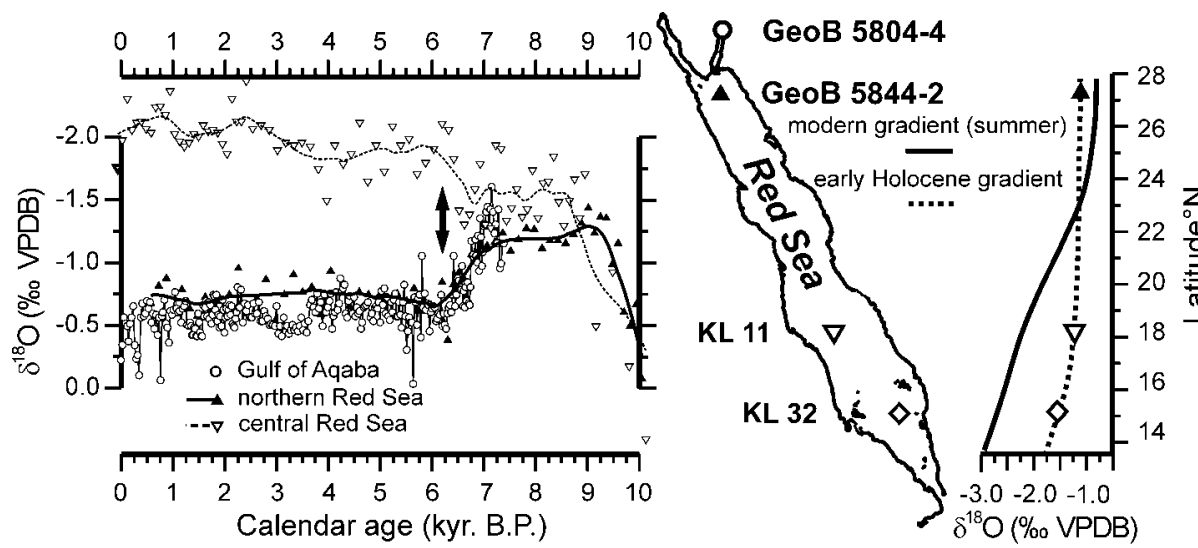

Fig. 4. Comparison of the Holocene $\delta^{18} \mathrm{O}$ records of $G$. ruber (white) from the northern Red Sea (cores GeoB 5844-2 and GeoB 5804-4) with a central Red Sea $\delta^{18} \mathrm{O}$ record of the same species [core KL 11 (16)]. Right panel shows the modern (20) and reconstructed early-Holocene $\delta^{18} \mathrm{O}$ gradient (30) along the Red Sea [both based on G. ruber (white)]. similar to the effect it probably had on human civilizations during the globally warm early to mid-Holocene.

References and Notes

1. G. H. Haug, K. A. Hughen, D. M. Sigman, L. C. Peterson, U. Rohl, Science 293, 1304 (2001).

2. F. Gasse, Quat. Sci. Rev. 19, 189 (2000).

3. P. Hoelzmann, H.-J. Kruse, F. Rottinger, Global Planet. Change 26, 105 (2000).

4. E. J. Rohling et al., Paleoceanography 13, 316 (1998).

5. M. Rossignol-Strick, Quat. Sci. Rev. 18, 515 (1999).

6. P. De Menocal et al., Quat. Sci. Rev. 19, 347 (2000).

7. U. Neff et al., Nature 411, 290 (2001).

8. S. J. Burns, A. Matter, N. Frank, A. Mangini, Geology 26, 499 (1998).

9. N. Roberts, H. E. J. Wright, in Global Climates Since the Last Glacial Maximum, H. E. J. Wright et al., Eds. (Univ. of Minnesota Press, Minneapolis, MN, 1993) Pp. 194-220.

10. S. P. Harrison, G. Yu, P. E. Tarasov, Quat. Res. 45, 138 (1996).

11. M. Rossignol-Strick, Paleogeogr. Paleoclimatol. Paleoecol. 49, 237 (1985).

12. A. E. Aksu, R. N. Hiscott, D. Yasar, Mar. Geol. 153, 275 (1999).

13. C.-P. F. Hsü, J. M. Walace, Month. Weath. Rev. 104, 607 (1976).

14. G. Eshel, N. H. Naik, J. Phys. Oceanogr. 27, 1233 (1997).

15. Materials and methods are available as supporting material on Science Online.

16. I. Schmelzer, thesis, University of Tübingen (1999).

17. H. W. Arz, J. Pätzold, P. J. Müller, M. O. Moammar, unpublished data.

18. M. Bar-Matthews, A. Ayalon, A. Kaufman, Chem. Geol. 169, 145 (2000).

19. N. Kallel et al., Oceanol. Acta 20, 697 (1997).

20. G. Ganssen, D. Kroon, in Special Section on Paleoceanography of Marginal Seas, R. Thunell, M. B. Cita, Eds. (American Geophysical Union, Washington, DC, 1991), vol. 6, pp. 73-82.

21. C. Hemleben et al., Paleoceanography 11, 147 (1996).

22. O. Marchal et al., Quat. Sci. Rev. 21, 455 (2002).

23. N. Rimbu, G. Lohmann, J.-H. Kim, H. W. Arz, R. Schneider, Geophys. Res. Lett., in press.

24. Budziak et al., Paleoceanography 15, 307 (2000).

25. F. Gasse, Quat. Sci. Rev. 21, 737 (2002).

26. M. Claussen et al., Geophys. Res. Lett. 26, 2037 (1999).

27. C. D. Hewitt, J. F. B. Mitchell, J. Clim. 9, 3505 (1996)

28. F. Giorgi et al., in Climate Change 2001: The Scientific Basis, J. T. Houghton et al., Eds. (Cambridge Univ. Press, Cambridge, 2001), chap. 10.

29. E. J. Rohling, P. A. Mayewski, R. H. Abu-Zied, J. S. L. Casford, A. Hayes, Clim. Dynam. 18, 587 (2002).

30. Early-Holocene $\delta^{18} \mathrm{O}$ gradients were estimated by averaging $\delta^{18} \mathrm{O}$ values from three $G$. ruber (white) records [GeoB 5844-2 (this study); cores KL 11 and KL 27 (15)] along the Red Sea for the maximum of the northern Red Sea humid interval ( $\sim 7.2$ to $9.2 \mathrm{ka}$ ).

31. We thank M. Segel and B. Meyer-Schack, University of Bremen for carrying out the stable isotope measurements. We also acknowledge the generous grant of permission for conducting research in the territorial waters of the Kingdoms of Jordan and Saudi Arabia with the German research vessel Meteor in March and April 1999. Supported by the DFG (grants PA 492/4-1 and PA 492/4-2) and as part of the DFG Research Center for Ocean Margins of the University of Bremen.

Supporting Online Material

www.sciencemag.org/cgi/content/full/300/5616/118/

DC1

Materials and Methods

SOM Text

Fig. S1

Table S1

References

11 November 2002; accepted 4 March 2003 